\title{
ADIK PKL ABG: AN ACTIVE LEARNING MODEL
}

\section{ADIK PKL ABG SEBUAH MODEL PEMBELAJARAN ACTIVE LEARNING}

\author{
Firdos Mujahidin \\ Balai Pendidikan dan Pelatihan Keagamaan Bandung \\ J. Soekarno HattaNo. 716 Bandung \\ Email: firdosmujahidin76@gmail.com
}

\begin{abstract}
The purpose of this research is to develop existing model, method, and approach into a new learning model as a series of activities, and it has been commonly practiced in learning. The research method used is Research and Development (R\&D) designed by Richey and Klien at the 3rd level. The research and development of this learning model is based on the theory of learning, primarily the theory of behavioristic, cognitive, constructivistic and active learning. The results showed that the learning model named "ADIK PKL ABG" can be applied in learning and successfully manage learning in an effective way. The name may have less positive perception in the future, thus more positive and elegant acronym is still in search.
\end{abstract}

Keywords: learning model; training; research and development

\section{PENDAHULUAN}

\section{Latar Belakang}

Kurikulum dan pembelajaran tidak dapat dipisahkan. Hal tersebut dapat dilihat dari komponen-komponen kurikulum yang sangat berkaitan dengan pembelajaran. Sebagaimana para ahli jelaskan bahwa Komponenkomponen kurikulum tersebut terdiri dari tujuan, materi pembelajaran, metode, dan evaluasi. Dalam bentuk sistem ini kurikulum akan berjalan menuju suatu tujuan pendidikan dengan adanya saling kerja sama di antara seluruh sub sistemnya. Jika salah satu dari variabel kurikulum tidak berfungsi dengan baik, maka sistem kurikulum akan berjalan kurang optimal. Selain itu dalam pelaksanaan kurikulum diperlukan suatu perencanaan dan pengorganisasian pada seluruh komponennya. (Huda, 2017). Kurikulum secara operasional diimplementasikan dalam pembelajaran. Untuk itu peranan metode pemebelajaran sebagai bagian dari komponen pembelajaran sangatlah penting.

Ada ungkapan bahwa tidak ada metode pembelajaran yang paling baik, namun semua metode adalah baik tergantung guru, materi dan kondisi pembelajaran yang ada. Metode-metode tersebut masing- masing memiliki kelebihan - kelebihan serta kekurangan-kekurangannya yang menjadi karakteristiknya. Dengan demikian tidak ada metode yang dianggap paling baik atau paling jelek untuk pembelajaran (Soemarmi, 2017). Ungkapan ini seakan menegaskan bahwa metode pembelajaran harus menyesuaikan dengan segala kondisi supaya menjadi metode yang baik sesuai dengan kondisi, tuntutan dan kebutuhan pembelajaran.

Perkembangannya, selanjutnya metode pembelajaran sering diistilahkan dengan model pembelajaran. Ahli ada juga yang mebedakan antara pendekatan pembelajaran, strategi pembelajaran, model pembelajaran, metode pembelajaran, teknik pembelajaran dan gaya mengajar guru. Namun Mujahidin menjelaskan bahwa apapun istilahnya apakah strategi, pendekatan, model, metode atau teknik, hal tersebut merupakan cara efektif yang 
dipilih pendidik agar pembelajaran efektif untuk mencapai tujuan pembelajaran yang sudah ditetapkan. (Mujahidin, 2017)

Pembelajaran yang lebih mengaktifkan peserta didik sering diistilahkan dengan active learning. Pembelajaran yang menekankan kepada keaktifan peserta didik telah melahirkan berbagai pendekatan dan model pembelajaran. Pendekatan yang banyak digunakan di antaranya adalah pendekatan Contextual Teaching and Learning (CTL) dan Pendekatan Saintifik. Sedangkan model pembelajaran yang banyak digunakan dalam praktik pembelajaran di Indonesia di antaranya; model pembelajaran kooperatif, model pembelajaran berbasis maslah, model pembelajaran berbasis proyek, model pembelajaran inquri, model pembelajaran discovery, dan sebagainya. Pentingnya tentang pembelajaran aktif (active learning) salah satunya dapat dilihat dari hasil penelitian Pernantah yang menjelaskan bahwa dengan pembelajaran aktif, maka peserta didik dapat belajar dengan mandiri dan mencapai tujuan secara efektif. Pembelajaran aktif dapat berlangsung dalam setiap tingkatan, mulai pendidikan rendah (Sekolah Dasar) samapi dengan perkuliahan. (Permantah, 2019). Begitu juga dengan pendekatan Saintifik dalam berbagai penelitian dijelaskanbahwa pendekatan saintifik merupakan pendekatan yang mengembangkan pembelajaran aktif bagi peserta didik dalam kurikulum 2013, bahkan pendekatan saintifik ini penting diterapkan bahkan dapat diterapkan mulai untuk pembelajaran anak usia dini. (Raharjo, 2019)

Tidak dapat dipungkiri bahwa setiap metode/model pembelajaran memiliki kelebihan dan kelemahan/kekurangan. Untuk itu pengembangan metode menjadi suatu keharusan agar kelebihan atau kekuatan metode atau model tersebut dapat diintegrasikan dan dilengkapi dengan langkah lainnya sesuai dengan model objek dan kondisi. Ada juga pemahaman bahwa pelaksanaan model pembelajaran harus sesuai dengan sintak (tahapan langkah-langkah) sebagaimana model tersebut, sehingga hal itu tidak sesuai dengan semangat pembelajaran modern yang mempunyai keberpihakkan terhadap kebutuhan peserta didik.

Perkembangan model pembelajaran telah melahirkan beberapa istilah atau juga nama model pembelajaran yang baru sebagai pngembangan dari model pembelajaran yang telah ada. Dengan sering mempraktikkan berbagai model pembelajaran, maka penulis tertarik menyusun kegiatan pembelajaran secara sistematis dan prosuderal sebagai pengembangan model pembelajaran sesuai dengan kebutuhan dan respon kondisi supaya pembelajaran lebih aktif.

Untuk apakah pembelajaran active learning dan model pembelajaran dalam dikembangkan menjadi model yang baru, yaitu ADIK PKL ABG, sebagai hasil peneltian dan pengembangan terhadap pembelajaran aktif, model pembelajaran dan pendekatan saintifik?, Maka peneliti meneliti dan mengembangkan supaya memperoleh suatu model tersebut yang berbeda dari model yang telah ada, baik nama maupun sintak model tersebut. Dan apakah model tersebut dapat mengelola pembelajaran lebih efektif?, pembelajaran yang seperti apakah yang efektif dengan model pembelajaran ADIK PKL ABG ini?

\section{Active learning dan Model Pembelajaran}

Pembelajaran tidak dapat dipisahkan dengan metode dan model pembelajaran. Pembelajaran banyak ahli yang mendefinisikannya. Dalam Kamus Besar Bahasa Indonesia (KBBI) online disebutkan bahwa pembelajaran Pembelajaran didefinisikan sebagai suatu proses, cara, perbuatan menjadikan orang atau makhluk hidup belajar. Sedangkan menurut para ahli pembelajaran didefiinisikan; mengaktualkan potensi menjadi kompetensi (Suderadjat, 2004). Pembelajaran adalah proses sama-sama peningkatan kompetensi antara pendidik dengan peserta didik (Mujahidin, 2017). Sedangkan dalam Kurikulum 2013 dijelaskan bahwa pembelajaran adalah proses peningkatan kompetensi dalam semua ranah peserta didik, baik sikap, pengetahuan maupun keterampilanna (Kementerian Pendidikan dan Kebudayaan, 2013).

Hasil penelitian tentang active learning menjelaskan bahwa pembelajaran aktif (active learning) adalah suatu proses pembelajaran dengan maksud untuk memberdayakan peserta Didik agar belajar dengan menggunakan berbagai cara/strategi Secara aktif. Dalam hal ini proses aktivitas pembelajaran didominasi oleh peserta didik 
dengan menggunakan otak untuk menemukan konsep dan memecahkan masalah yang sedang dipelajari, di samping itu juga untuk menyiapkan mental dan melatih keterampilan fisiknya (Effendi, 2013). Hal yang senada juga terdapat dalam penelitiannya (Malik, 2008), (Zuriah, Sunaryo, \& Yusuf, 2016), atau (Emilia \& Gunawan, 2012).

Pembelajaran aktif merupakan pembelajaran yang mengajak peserta didik untuk belajar secara Doing Self Observing Others aktif, artinya mereka mendominasi aktivitas pembelajaran. Dengan belajar aktif ini, peserta didik diajak untuk turut serta dalam semua proses pembelajaran, tidak hanya mental akan tetapi juga fisik. Dengan cara ini, biasanya peserta didik akan merasakan suasana yang lebih menyenangkan sehingga hasil belajar dapat dimaksimalkan dan siswa tidak pasif lagi dalam belajar (Arifin dan Setiyawan, 2012).

Perlunya pembelajaran aktif diungkapkan oleh Sophocles (Yunani) "Seseorang harus belajar dengan cara melakukan sesuatu, karena walaupun Anda berpikir telah mengetahui sesuatu, Anda tidak akan memiliki kepastian tentang hal tersebut sampai Anda mencoba melakukan sendiri". Identik dengan filosofis Cina, Confusius mengatakan: What $i$ hear, $i$ forget What $i$ see, $i$ remember, and What $i$ do, $i$ understand Apa yang saya dengar, saya lupa Apa yang saya lihat, saya ingat, dan Apa yang saya lakukan, saya memahami Hasil modifikasi. Silberman (2013: 23) atas pernyataan Confucius di atas adalah sebagai berikut: What $i$ hear, i forget. What $i$ hear and see, i remember a little. What $i$ hear, see, and ask question about or discuss with someone else, $i$ begin understand. What $i$ hear, see, discuss, and do, i acquire knowlegde and skill. What $i$ teach to another, $i$ master. Apa yang saya dengar, saya lupa. Apa yang saya dengar dan lihat, saya ingat sedikit. Apa yang saya dengar, lihat dan tanyakan atau diskusikan dengan beberapa kolega atau teman, saya mulai paham. Apa yang saya dengar, lihat, diskusikan dan lakukan, saya memperoleh pengetahuan dan keterampilan. Apa yang saya ajarkan pada orang lain, saya menguasainya. Berdasarkan hasil modifikasi dan penyempurnaan Confucius di atas, dapat dipahami bahwa konsep active learning Silberman menghendaki peserta didik yang tidak hanya mendengar, melainkan juga melihat supaya lebih paham walaupun sedikit, mendiskusikannya agar memahami atau mendalami, melakukannya agar memperoleh pengetahuan, dan mengajarkannya agar menguasainya. (Warsono dan Hariyanto,2013)

Pendapat para ahli di atas menyimpulkan bahwa model pembelajaran aktif (active learning) adalah model pembelajaran dimana siswa berperan secara aktif dalam kegiatan belajar baik dalam bentuk interaksi antar peserta didik ataupun peserta didik dengan guru dalam proses belajar, siswa tidak hanya mendengarkan informasi dari guru, tetapi siswa melakukan eksplorasi dan mengalaminya sendiri seperti menemukan, melihat, mencoba, bertanya dan memecahkan masalah.

Pembelajaran aktif memadukan teori-teori belajar, terutama teori belajar behavioristik dan teori belajar kogniitif. Teori-teori belajar tersebut menuntut adanya aktivitas fisik dan mental peserta didik dalam belajar. Teori-teori tersebut berdasakan kepada ujicoba yang menghasilkan kondisi ideal seseorang untuk belajar secara optimal. Seperti bagaimana teori behavioristik mengungkapkan bahwa benar dan salah itu bergantung pada reinforcement (penguat) positif maupun negatif. Artinya jika ada stimulus dan setelah direspon ternyata menimbulkan "keenakan", maka tingkah laku itu dikatakan benar, dan jika respon tersebut menimbulkan reinforcement negatif, maka perbuatan tersebut salah. Dengan kata lain, belajar merupakan bentuk perubahan yang dialami siswa dalam hal kemampuannya untuk bertingkah laku dengan cara yang baru sebagai hasil interaksi antara stimulus dan respon. (Hayati, 2017 dan Umam, 2019)

Sedangkan teori belajar kognitif secara umum mengasusmsikan setiap orang telah memiliki pengetahuan dan pengalaman yang telah tertata dalam bentuk struktur kognitif yang dimilikinya. Proses belajar akan berjalan dengan baik jika materi pelajaran atau informasi baru beradaptasi dengan struktur kognitif yang telah dimiliki seseorang. Sedangkan dalam teori belajar konstruktivistik dijelaskan bahwa membangun pengetahuan sedikit demi sedikit, yang kemudian hasilnya diperluas melalui konteks yang terbatas dan tidak sekoyong-koyong. Pengetahuan bukanlah seperangkat fakta-fakta, konsep-konsep, atau kaidah yang siap untuk diambil atau diingat. Manusia harus mengkonstruksi pengetahuan itu dan memberi makna melalui pengalaman nyata. 
(Hayati, 2017 dan Umam, 2019). Dari teori-teori belajar di atas, maka melahirkan berbagai bentuk pembelajaran salah satunya pembelajaran aktif yang dikembangkan oleh Silberman (2013).

Pembelajaran aktif memiliki karakteristik sebagai berikut: 1) Penekanan proses pembelajaran bukan pada penyampaian informasi oleh pengajar melainkan pada pengembangan keterampilan pemikiran analitis dan kritis terhadap topik atau permasalahan yang dibahas. 2) Peserta didik tidak hanya mendengarkan pelajaran secara pasif tetapi mengerjakan sesuatu yang berkaitan dengan materi pelajaran. 3) Penekanan pada eksplorasi nikainilai atau sikap-sikap berkenaan dengan materi pelajaran. 4) Peserta didik lebih banyak dituntut untuk berpikir kritis, menganalisis dan mengevaluasi. 5) Umpan balik yang lebih cepat akan terjadi pada pembelajaran. Dapat disimpulkan bahwa karakteristik pembelajaran aktif adalah mengembangkan sikap kritis, analitis, aktif bagi peserta didik dalam memberikan feedback materi yang diajarkan oleh guru. (Arifin dan Setiyawan, 2012)

Sukmadinata dan Syaodih (2012) menjelaskan bahwa model pembelajaran yang baik memiliki beberapa karakteristik, yaitu memiliki prosedur ilmiah, hasil belajar yang spesifik, kreteria hasil belajar dan proses pembelajaran yang jelas. Setiap metode/model pembelajaran dapat memiliki karakteristik yang disebutkan di atas, yaitu dengan cara mengintegrasikan semua langkah pembelajarannya disesuaikan dengan tujuan pembelajaran dan materi pembelajarannya, sehingga proses dan hasil belajarnya akan spesifik mengacu kepada tujuan pembelajaran yang telah ditetapkan, yaitu KD dan indikator.

Model pembelajaran merupakan petunjuk bagi pendidik dalam merencanakan pembelajaran di kelas, mulai dari mempersiapkan perangkat pembelajaran, media dan alat bantu, sampai alat evaluasi yang mengarah pada upaya pencapaian tujuan pelajaran (Mirdad, 2020). Mengembangkan metode pembelajaran modern dan komnvensional dibutuhkan adanya metode resistensi yaitu ada kemampuan guru "mendengarkan" siswa mampu berbicara, membaca, mempraktekkan dan melakukan tindakan pembelajaran secara tentatif dan konstruktif, agar mampu menciptakan nuansa pembelajaran yang lebih hidup, mudah dan cermat. (Dewi, 2018).

Trianto mendefiniskan model pembelajaran adalah kerangka konseptual yang menggambarkan prosedur sistematik dalam mengorganisasikan pengalaman belajar untuk mencapai tujuan belajar tertentu dan berfungsi sebagai pedoman bagi perancang pembelajaran dan para guru dalam merancang dan melaksanakan pembelajaran. (Trianto, 2010)

Model pembelajaran memiliki ciri-ciri sebagai berikut: 1) Berdasarkan teori pendidikan dan teori belajar dari para ahli tertentu. 2) Mempunyai misi atau tujuan pendidikan tertentu. 3) Dapat dijadikan pedoman untuk perbaikan kegiatan belajar mengajar dikelas. 4) Memiliki bagian-bagian model yaitu urutan langkah-langkah pembelajaran (syntax), adanya prinsip-prinsip reaksi, sistem sosial dan sistem pendukung. 5) Memiliki dampak sebagai akibat terapan model pembelajaran. (Rusman, 2011)

Active learning dan model pembelajaran sangat terkait. Keterkaitan itu adalah dapat ditelaah bahwa active learning dan model pembelajaran yang ada menekankan terhadap keaktifan peserta didik dalam pembelajaran (student centered) dan memposisikan guru sebagai fasilitator, yaitu yang memfasilitasi supaya kebutuhan peserta didik akan berbagai potensi, minat, bakat serta kompetensinya. Untuk itu sebuah kemustahilan jika active laerning dan model pembelajaran tidak dikembangkan sesuai dengan kebutuhan dan keunikan sekolah/madrasah/lembaga pendidikan (satuan pendidikan) lainnya maupun keunikkan peserta didik/pelatihan di lembaga penddikan tersebut.

\section{METODOLOGI}

Metode penelitian dalam penulisan artikel ini adalah metode Penelitian dan Pengembangan (Reaseach and Development/R\&D). Metode penelitian ini menurut Sugiyono adalah cara ilmiah untuk meneliti, merancang, memproduksi dan menguji validitas produk yang dihasilkan. Ada 4 level dalam metode penelitian R\&D ini, yaitu; 1) menelti tanpa membuat dan menguji produk; 2) tanpa meneliti, hanya menguji produk yang telah ada; 3 ) meneliti dan mengembangan produk yang telah ada; dan 4) meneliti dan menciptakan produk baru (Sugiyono, 2019). 
Peneliti dalam penelitian ini menggunakan metode R\&D pada level 3 , yaitu meneliti dan mengembangan produk yang telah ada. Meneliti model-model pembelajaran yang telah ada dan mengembangkankannya dengan menyusun pola baru dan memberikan nama atau istilah baru untuk model pembelajaran yang diteliti dan dikembangkan. Desainnya menggunakan pola sebagaimana yang diungkapkan oleh Richey and Klein (2009) yang mengungkapkan bahwa pola penelitian dalam R\&D adalah Planing, Production and Evaluation. Planing (Perancangan) adalah perencanaan akan produk akan dibuat dengan mengkaji literasi dan praktik produk yang akan dihasilkan. Production (memproduksi) adalah kegiatan membuat produk berdasarkan rancangan yang telah dibuat. Dan Evaluation (evaluasi) merupakan kegiatan menguji, menilai seberapa tinggi produk yang telah menenuhi kualifikasi sebagaimana yang telah ditentukan.

Evaluasi terhadap model pembelajaran ini dilakukan dalam beberapa uji coba pelatihan, yaitu di Pelatihan di Balai Diklat Keagamaan Bandung rentang tahun 2020 pada beberapa kegiatan diklat/pelatihan, seperti Pelatihan Penguatan Kompetensi Kepala Madrasah (di Kabupaten Garut, Cianjur dan Ciamis, 3 KegiatanDiklat/Pelatihan), Diklat/Pelatihan Guru PAI pada Pelatihan di Tempat Kerja (PDWK) di Kab.Indramayu dan di Kota Cirebon. Diulang-ulang ujicoba penerapan model tersebut sampai ditemukan berbagai gambaran tentang efektifnya model pembelajaran tersebut. Di sini peneliti berkedudukan sebagai peneliti dan pegembang sekaligus verifikator dalam penembangan model pembelajaran ini.

Peneliti dalam penelitian ini, menelaah model pembelajaran terutama model-model atau pendekatan yang dianjurkan untuk digunakan dalam pembelajaran, seperti pendekatan saintifik, model pembelajaran kooperatif, model pembelajaran berbasis masalah, model pembelajaran berbasis proyek, model pembelajaran inquiri dan model pembelajaran discovery. Memproduksi dengan membuat langkah-langkah baru dalam model pembelajaran, yaitu nama model dan langkah-langkahnya dan mengevaluasi model tersebut, yaitu dengan mengujicobakan model tersebut dalam pembelajaran dan memperbaiki langkah-langkah model tersebut yang dilakukan oleh peneliti.

\section{HASIL DAN PEMBAHASAN \\ Hasil}

Tiga langkah penelitian dan pengembangan menurut model Richey dan Klein menunjukkan hasil bahwa ketiganya harus dilakukan secara terintegrasi dan berkesinambungan, sehingga langkah perancangan, memproduksi dan mengevaluasi merupakan langkah-langkah yang antara satu dengan yang lainnya mempunyai keterkaitan yang erat dan tidak dapat dipisahkan. Planing (Perancangan) sebagai langkah pertama, yaitu perencanaan akan produk akan dibuat dengan mengkaji literasi dan praktik produk yang akan dihasilkan. Dalam keiatan ini mengkaji menelaah model pembelajaran terutama model-model atau pendekatan yang dianjurkan untuk digunakan dalam pembelajaran, seperti pendekatan saintifik, model pembelajaran kooperatif, model pembelajaran berbasis masalah, model pembelajaran berbasis proyek, model pembelajaran inquiri dan model pembelajaran discovery. Hasil pada tahap ini menunjukkan bahwa pendekatan saintifik dan model-model yang dianjukan untuk digunakan dalam pembelajaran kurikulum 2013 atau dalam pembelajaran lainnya, seperti pelatihan dan perkuliahan hendaknya menitikberatkan kepada kegiatan atau pengalaman belajar siswa/peserta didik. Pendekatan saintifik mengharuskan peserta didik mengalami dan berkegiatan dengan 5M, yaitu Mengamati, Menanya, Mengumpulkan Informasi, Mengasosiasi dan Mengomunikasikan. Langkah kegiatan pendekatan saintifik boleh tidak berurutan asal setiap pertemuan pembelajaran peserta didik mempunyai pengalaman belajar atau kegiatan belajar 5M.

Di sisi lain, model pembelajaran mempunyai sintak (langkah-langkah) kegiatan dalam pembelajaran yang harus dilakukan secara berurutan, karena secara rasional langkah-langkah tersebut telah disusun secara sistematis dan prosedural dilakukan oleh peserta didik melalui desain pendidik. Akhiryna ada dua hal yang menarik digabungkan, suatu sisi pendekatan saintifik tidak menuntut kegiatan berurutan, sedangkan sisi yang lain model pembelajaran menuntut langkah kegiatan yang berurutan. Dengan demikian, maka perlu ada model pembelajaran yang mengintegrasikan pendekatan saintifik dengan model-model pembelajarannya yang telah 
dianjurkan. Langkah-langkah tersebut sesuai dengan singkatannya ADIK PKL ABG, langkah-langkahnya, yaitu Amati, Diskusi, Improvisasi, Karya, Presentasi, Konfirmasi/Klarifikasi, Laporkan, Apresiasi, Berkesinambungan dan Gembira. ADIK PKL merupakah langkah kegiatan, sedangkan ABG lebih pada sifat dari pembelajaran yang dilaksanakan.

Production (memproduksi), yaitu kegiatan membuat produk berdasarkan rancangan yang telah dibuat. . Memproduksi dengan membuat langkah-langkah baru dalam model pembelajaran, yaitu nama model dan langkah-langkahnya. Nama model pembelajaran dilakukan setelah langkah-langkah pembelajaran selesai ditetapkan. Dalam prosesnya penamaan itu merupakan langkah akhir setelahnya langkah-langkah pembelajaran (sintaks) ditetapkan. Langkah-langkah pembelajaran yang dirumuskan dapat dilihat dari bagan di bawah ini:

Gambar:

Sintak Model Pembelajaran "ADIK PKL ABG"

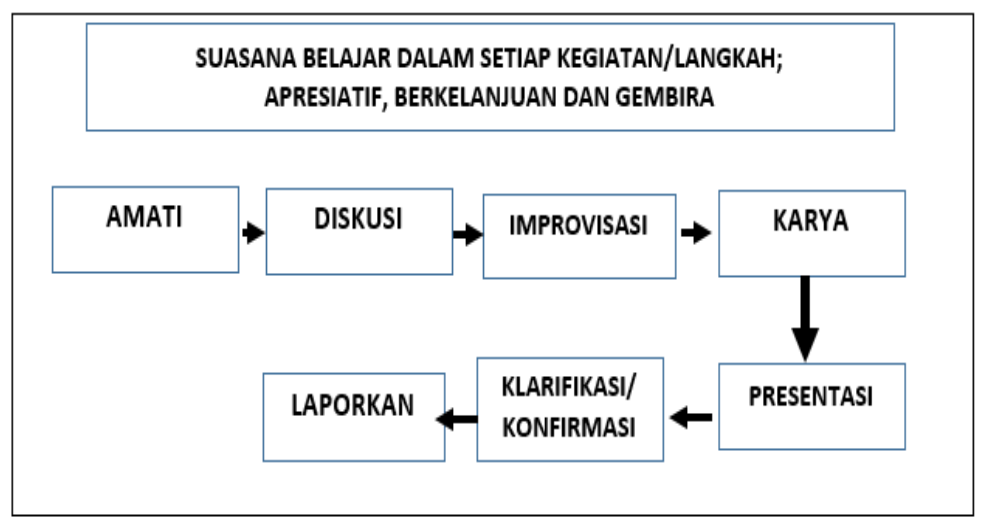

Sedangkan Evaluation (evaluasi), yaitu kegiatan menguji, menilai seberapa tinggi produk yang telah menenuhi kualifikasi sebagaimana yang telah ditentukan. mengujicobakan model tersebut dalam pembelajaran dan memperbaiki langkah-langkah model tersebut. Hasil ujicoba menunjukkan; 1) pada diklat penguatan kepala madrasah efektif dan sesuai tahapan, namun improvisasi yang masih kurang, kecuali peerta pelatihannya kepa Raudhatul Athfaal (RA) di Garut, tingkat improvisasinya tinggi, 2) Pada pelatihan Guru PAl di Kab. Indramayu dapat diimplementasikan degan baik,namun improvisasi kurang dan karyanya masih sederhana, dan 3) pada pelatihan guru PAI di Kota Cirebo setiap langkah dapat dilaksanakan dengan penuh dan pembelajarnyapun sangat efektif. Hasil ke- 3 dapat lebih baik karena penelti terus menyempurnakan dan menindaklanjuti setiap kekurangan pada kegiatan-kegiatan sebelumnya.

ADIK PKL ABG adalah model pembelajaran dengan langkah pembelajaran Amati-Diskusi-Improvisasi-KaryaPresentasi-Klarifikasi-Laporkan-Apresiasi-Berkelanjutan dan Gembira. Istilah atau nama model tersebut dan bagiannya telah mengalami berbagai perubahan, terutama kepanjangkan DiK asalnya hanya Diskusi Karya, kemudian berubah menjadi Diskusi Inovasi dan Karya. Kemudian terakhir menjadi Diskusi Improvisasi dan Karya. Hal ini setelah mengalami beberapa ojicoba dan kajian bahwa improvisasi jauh lebih luas maknanya dari inovasi/inovatif dan juga menyesuaikan dengan trend belajar yang memerkedakan. Improvisasi lebih memerdekakan guru dalam mengelola proses pembelajaran.

\section{Pembahasan}

Secara umum model pembelajaran dengan langkah kegiatan Amati-Diskusi-Improvisasi-Karya-PresentasiKlarifikasi-Laporkan-Apresiasi-Berkelanjutan dan Gembira (ADIK-PKL-ABG). Amati kegiatan peserta mendengarkan, menyimak, menonton, menyaksikan hal-hal yanyg berkaitan dengan materi baik bersumber dari narasumber (Widyaiswara) atau dari peserta berupa bahan ajar ( bahan tayang, video, dll.). 
Diskusi adalah salah satu dari metode pembelajaran. Metode diskusi merupakan suatu metode mengajar yang dapat memecahkan persoalan-persoalan yang dapat dipecahkan secara bersama dengan bertukar pikiran dengan mufakat bersama antara anggota kelompok dan peserta diskusi. Metode diskusi adalah cara penyajian pelajaran, di mana siswa-siswa dihadapkan kepada suatu masalah, yang bisa berupa pernyataan atau pertanyaan yang bersifat problematis untuk dibahas dan dipecahkan bersama. (Safruddin, 2017). Dalam model ini, diskusi dapat berbasis masalah, dapat juga berbasis proyek yang harus diselesaikan, atau mencari sesuatu (discovery dan Inquiri) atau juga menyelesaikan kasus atau lembar kerja yang disediakan pendidik (guru/dosen/widyaiswara/instruktur/fasilitator) dalam pembelajaran sesuai dengan hasil pengamatan dalam kegiatan Amati di atas. Diskusi di model ini juga dapat mengimplementasikan secara menyeluruh langkah kegiatan pendekatan saintifik, baik Mengamati (mendengar pendapat anggota kelompok diskusi), langkah menanya, mengumpulkan informasi, mengasosiasi dan mengomunikasikan yang dapat dilakukan dalam kelompok diskusinya.

Improvisasi merupakan langkah yang mengarahkan peserta didik untuk mememberikan sesuatu yang berbeda dari biasanya. Prinsipnya adalah "beda dan unggul", beda dari yang lain tapi lebih baik. Improvisasi dalam KBBI online diartikan; 1) pembuatan (penyediaan) sesuatu ber-dasarkan bahan yang ada (seadanya); dan 2) penciptaan atau pertunjukan sesuatu (pembawaan puisi, musik, dan sebagainya) tanpa persiapan lebih dahulu. Improvisasi dalam model pembelajaran ini adalah kegiatan yang memberikan kebebasan peserta didik/pelatihan untuk menentukan langkah-langkah diskusi dikelompoknya, hasil karya yang akan dihasilkan serta improvisasi lainnya sejauh improvisasi tersebut sesuai dengan tujuan pembelajaran yang telah ditetapkan.Improvisasi juga dalam menghasilkan produk, jadi ada improvisasi proses dan produk.

Karya di KBBI online salah satu artinya adalah hasil perbuatan; buatan; ciptaan (terutama hasil karangan). Karya dalm model pembelajaran ini adalah diskusi kelompok yang diberikan tugas membahas sesuai yang akhirnya menghasilkan produk atau karya bisa berupa peta konsep, mind mapping, Tabel, gambar atau lainnya sesuai dengan penugasan yang nantinya akan dipresentasikan ke semua peserta didik. Karya yang dihasilkan sebaiknya dilombakan dan saling menilai karya, sehingga peserta didik/pelatihan akan membuat karya sebaik mungkin. Karya ini kalau dalam pendekatan saintifik lebih kepada kegiatan mengasosiasi. Dalam taksonomi Bloom yang sudah direvisi ini termasuk langkah kognisi tertinggi yaitu termasuk pada membuat/mencipta (create).

Presentasi di KBBI online salah satu artinya adalah penyajian atau pertunjukan. Presentasi adalah kegiatan menunjukkan hasil kerja di kelompok masing-masing untuk tugas/tema tertentu supaya mendapat tanggapan dari kelompok lainnya. Klarifikasi adalah kegiatan untuk menilai hasil kerja kelompok sesuai dengan kriteria atau standar kebenaran yang dapat dipertanggungjawabkan.

Klarifikasi di KBBI online adalah penjernihan, penjelasan, dan pengembalian kepada apa yang sebenarnya (tentang karya ilmiah dan sebagainya). Kegiatan klarifikasi dalam model pembelajaran ini adalah kegiatan memberi tanggapan hasil (karya) kelompok, menambahkan, membenarkan dan menguatkan dan kegiatan lainnya yang mengarahkan hasil kelompok tersebut menjadi sebuah hasil yang sempurna dan benar menurut teori, peraturan, kaidah, norma, nilai atau menurut kriteria lainnya. Klarifikasi dapat dilakukan terlebih dahulu oleh peserta didik dengan melakukan saling klarifikasi terhadap berbagai pendapat, pernyataan, pertanyaan, masalah atau apapun yang dibahas. Tahap akhir klarifikasi dilakukan oleh pendidik (guru, dosen, widyaiswara, dII.) dengan menambahkan kekurangan atau menguatkan yang sudah benar dari peserta didik/diklat atau meluruskan/membenarkan yang masih kurang sesuai dengan teori dan regulasi serta mempetegas/menguatkan hasil pembahasan yang sudah sesuai dengan regulasi/teori/kaidah/kriteria yang seharusnya.

Dan kegiatan yang terakhir adalah Laporkan. Laporan Hasil pembahasan secara komprehensif dapat menjadi umpan balik bagi kelompok untuk mengempurnakan produk diskusinya dan selanjutkan dibuat laporan hasilnya berupa produk yang diserahkan kepada pendidik (guru/dosen/widyaiswara/panitia atau pihak yang berkepentingan). Laporan itu juga akan menunjukkan kinerja kelompok dan kualitas diskusi dan karya suatu 
kelompok. Dengan adanya proses pelaporan sekaligus penilaian yang dilakukan oleh pendidik, maka proses diskusi, impropisasi, karya dan kegiatan lainnya akan dilakakan oleh peserta didik sebaik mungkin.

Supaya suasana pembelajaran menyenangkan dan membahagiakan maka suasana pembelajarannya harus ABG, yaitu Apresiasi sekecil apapun konstribusi peserta diklat, Berkelanjutan manfaat dari diklat dapat ditindaklanjuti dan dilakukan oleh peserta dan selalu dibawa kepada suasana gembira biar mereka bahagia dan senang. Sehingga pembelajarannya menjadi lebih efektif. Prinsip merupakan keadaan yang sederhana dari kegiatan yang secara lebih lengkapnya Mujahidin mengatakan sebagai kegiatan "PAIKEMI GEMBROT DASTER BOLONG PISAN" Pembelajaran yang Aktif, Inovatif, Kreatif, Efektif, Menyenangkan, Menggembirakan, Rasional dan Berbobot, Mencerdaskan dan Berkarakter, Berorientasi pada Long Life Education, membiasakan peserta didik Berpikir dan menciptakan Kesan (Mujahidin, 2017).

Langkah-langkah pembelajaran dalam model pembelajaran ADIK PLK ABG efektif dalam mengelola pembelajaran yang lebih aktif, pengembangankan minat dan bakat peserta didik sesuai dengan karakteristik, keunikkan, minat dan bakat peserta didik.Selain itu dengan mdel ini semua ranah yang harus ditingkatkan kemungkinan akan tercapai, baik ranah afektif (sikap), kognitif (pengetahuan) dan psikomotorik (keterampilan). Sikap yang lebih dikembangkan adalah sikap gotong royong, kerjasama, menalar kritis dan kreatif, toleransi, dan sikap lainnya. Pengetahuannya yang diperoleh akan lebih mendalam juga karena peserta didik "dipaksa" untuk berkarya dan berimprovisasi, sehingga dengan berkarya, maka pengetahuana dan keterampilan dapat dilakukan sekaligus (terintegrasi).

Hasil peneltian menunjukkan bahwa dengan ADIK PKL ABG; 1) pesert didik lebih aktif dalam pembelajaran; 2) mencipatakan persaingan yang sehat; 3) menumbuhkan pikiran kritis; 3) disiplin, kerjasama dan gotong royong; 4)pruduknya tidak asal-asalnya karena akan dipresentasikan (dinilai oleh peserta didik yag lain); produk/karya lebih baik dari sebelumnya karena akan ditla'aah); dan 5) interkasi antar peserta didik menjadi lebih kondusif dan produktif.

Model pembelajaran ini cocok digunakan oleh pendidik yang mempunyai alokasi waktu pembelajaran cukup panjang (durasi panjang), seperti dalam pelatihan atau pembelajaran dengan durasi waktu yang lama (minimal 3 Jam Pelajaran). Namun demikian keterampilan pendidik dalam memahami dan mempraktikkan model ini dapat juga membantu dalam menerapkan model pembelajaran ini dan mengelola pembelajaran lebih efektif.

\section{SIMPULAN}

Model pembelajaran ADIK PKL ABG adalah model pembelajaran yang merupakan pengembangan dari pendekatan saintifik dan model pembelajaran yang telah ada terutama model pembelajaran yang mengarahkan kepada active learning. Model pembelajaran ini didasarkan pada teori belajar behavioristik, kognitif, konstruktivistik dan teori pembelajaran aktif. Model pembelajaran ini akan lebih efektif diterapkan terhadap pembelajaran dengan durasi waktu yang lama, seperti pelatihan. Sebagaimana hasil penelitian dan ujicoba dari model ini yang diimplementasikan dalam kegiatan pembelajaran pelatihan atau pembelajaran lainnya dengan waktu yang lama supaya efektif mencapaitujuan pembelajaran dan langkah pembelajaran terlaksana dengan utuh.

\section{PUSTAKA ACUAN}

Agustyaningrum, Ni. (2010). Implemantasi Model Pembelajaran Learning Cycle 5E untuk meningkatkan kemampuan matematis siswa kelas IXB SMP Negeri 2 Sleman. UNY Yogyakarta.

Aji, W. N. (2016). Model Pembelajaran "Dick adn Carrey" dalam Pembelajaran Bahasa dan Sastra Indonesia. Kajian Linguistik Dan Sastra, 1(2), 119-126.

Dewi, E. Ratna. (2018). Metode Pembelajaran Modern Dan Konvensional Pada Sekolah Menengah Atas. Pembelajar Jurnal IImu Pendidikan, Keguruan dan Pembelajaran, 2(1). 4452. https://doi.org/10.26858/pembelajar.v2i1.5442

Effendi, Mukhlison. (2013). Integrasi Pembelajaran Active learning dan Internet Based Learning dalam 
Meningkatkan Keaktifan dan Kreatifitas Belajar. Nadwa Jurnal Pendidikan Islam, 7(2), 283-308. DOI : 10.21580/nw.2013.7.2.563

Emilia, E., \& Gunawan, M. H. (2012). CONTEXTUAL TEACHING AND LEARNING APPROACH TO Intan Satriani. IJAL-UPI, 2(1), 10-22.

Howard, J. (2007). Curriculum Development, 1-7.

Humammedi. (2013). Perubahan kurikulum di indonesia: studi kritis tentang upaya menemukan kurikulum pendidikan islam yang ideal, 49-70.

Huda, Nurul. (2017). Manajemen Pengembangan Kurikulum. Al-Tanzim Jurnal Majemen Pendidikan Islam, 1(2), 52-75, https://doi.org/10.33650/al-tanzim.v1i2.113

Hayati, Sri. (2017). Belajar dan Pembelajaran Berbasis Cooverative Learning. Magelang: Graha Cendekia

Huda, Nurul. (2017). Manajemen Pengembangan Kurikulum. Al-Tanzim Jurnal Majemen Pendidikan Islam, 1(2), 52-75, https://doi.org/10.33650/al-tanzim.v1i2.113

Machali, I. (2014). Kebijakan Perubahan Kurikulum 2013 dalam Menyongsong Indonesia Emas Tahun 2045, IIII, 71-94. https://doi.org/10.14421/jpi.2014.31.71-94

Malik, H. K. (2008). Teori Belajar Andragogi dan Aplikasinya dalam Pembelajaran. Inovasi, 5(2), 1-16.

Mirdad, Jamal. (2020). Model-Model Pembelajaran (Empat Rumpun Model Pembelajaran). (Indonesia jurnal Sakinah) Jurnal Pendidikan dan Sosial Islam, 2(2). 14-23, http://www.jurnal.stitnusadhar.ac.id

Mujahidin. Firdos. (2017). Strategi Mengelola Pembelajaran Bermutu. Bandung: Remaja Rosda Karya

Mujahidin. Firdos. (2018). Pengelolaan Pembelajaran Diklat Berbasis Model Teams. Tatar Pasundan Jurnal Diklat Keagamaan, XII (34), 177-190. https://doi.org/10.38075/tp.v12i34.68

Permantah, P. Setri. (2019). Desain Skenario Pembelajaran Aktif Dengan Metode "Mikir" Pada Mata Kuliah Pendidikan IPS. IJSSE: Indonesian Journal of Social Science Education, 1 (2), 145155,http://dx.doi.org/10.29300/ijsse.v1i2.1929

Prawira, Y. A. (2012). REVIEW OF TEACHING BASIC SKILLS AS A BASED OF TEACHING AND LEARNING STRATEGIES THE CURRENT APPROACH IN INDONESIAN EDUCATION. Tatar Pasundan: Jurnal Diklat Keagamaan Bandung. Retrieved from bdkbandung.kemenag.go.id

Raharjo, M. Melita. (2019). Implementasi Pendekatan Saintifik Sebagai Pembentuk Keterampilan Proses Sains Anak Usia Dini. Scholaria: Jurnal Pendidikan dan Kebudayaan, 9(2), 148-159.

Richey C. Rita; Klein D James. (2009). Design and Development Research;Routledge; New York, London

Safruddin.(2017). Implementasi Metode Diskusi Terhadap Peningkatan Hasil Belajar Siswa. CIRCUIT: Jurnal IImiah Pendidikan Teknik Elektro,1(1), 63-73

Saputra, A. (2014). Aplikasi Pembelajaran Kontekstual. Jurnal Ad-Ta'dib.

Subhi, T. A. (2016). KONSEP DASAR, KOMPONEN DAN FILOSOFI KURIKULUM PAI, 3(1), 117-134.

Sulfemi, W. B. (2018). Manajemen kurikulum di sekolah.

Siberman, Melvin L. 2013. Active learning: 101 Cara Belajar Siswa Aktif. rev. ed. Bandung: Penerbit Nuansa Cendikia.

Soemarmi, Karjati. (2017).Upaya Meningkatkan Kemampuan Berbicara Bahasa Jepang melalui Metode Bermain Peran (Role Play). Briliant Jurnal Jurnal Riset dan Konseptual, 2 (2),225-230.

Suderadjat, Hari. (2004). Implementasi Kurikulum Berbasis Kompetensi (KBK): Pembaharuan Pendidikan dalam Undang-Undang Sisdiknas 2003.Bandung: Cipta Cekas Grafika

Sugiyono. (2019) Metode Penelitian Pendidikan (Kuantitatif, Kualitatif, Kombnasi R\&D dan Penelitian Pendidikan). Bandung: Alfabeta Edisi 3 Cet-1

Sukmadinata, N.,Sy. dan Syaodih, Erliana. (2012). Kurikulum \& Pembelajaran Kompetensi. Bandung: Refika Aditama.

Rusman. (2011). Model-model Pembelajaran: Mengembangkan Profesionalisme Guru. Jakarta: Rajawali Pers. 
Umam, M. Khoirul. (2019). Studi Komparatif Paradigma Teori Belajar Konvensional Barat Dengan Teori Belajar Islam. Jurnal Kependidikan dan Syariah, 7 (2), 57-80.

Warsono dan Hariyanto. (2013). Pembelajaran Aktif. Bandung: PT Remaja Rosdakarya.

Peraturan Menteri Pendidikan dan Kebudayaan RI Nomor 22 Tahun 2016 tentang Standar Proses. 